\title{
Efek Variasi Suhu Pemadatan Campuran Laston Lapis Pondasi ( $A C$-Base) dengan Penambahan Limbah Plastik
}

\author{
Amalia Firdaus Mawardi ${ }^{1, *}$, Machsus Machsus ${ }^{1}$, Mohamad Khoiri ${ }^{1}$, Hertanto Gunawan ${ }^{1}$ \\ Departemen Teknik Infrastruktur Sipil, Institut Teknologi Sepuluh Nopember, Surabaya ${ }^{1}$ \\ Koresponden*, Email: amaliafwirawan@gmail.com
}

\begin{tabular}{|c|c|c|}
\hline \multicolumn{2}{|c|}{ Info Artikel } & Abstract \\
\hline Diajukan & 22 Januari 2020 & This paper discusses the effects of compaction temperature variations on Marshall \\
\hline Diperbaiki & 23 Januari 2020 & characteristics on the Laston Layer Base (AC-Base) Mixture with the addition of Plastic Waste, \\
\hline Disetujui & 24 Januari 2020 & $\begin{array}{l}\text { Polyethylene Terephthalate (PET) type. The method of mixing PET plastic waste is the we } \\
\text { method. Variation in compaction temperature between } 100^{\circ} \mathrm{C}-180^{\circ} \mathrm{C} \text { with an increase every } \\
10^{\circ} \mathrm{C} \text {. This study refers to the general specifications of the Ministry of Public Works Revised } \\
\text { III Public Works in } 2010 \text {. The results show that the density, Void Filled with Asphalt (VFA), } \\
\text { stability, and Marshall Quotient (MQ) values increase when the compaction temperature is } \\
\text { higher, both on AC-Base without or with the addition of PET plastic. Conversely, the value of }\end{array}$ \\
\hline $\begin{array}{l}\text { Keywords: } \\
\text { base, marsh } \\
\text { temperature }\end{array}$ & $\begin{array}{l}\text { terephthalate, } A C \text { - } \\
\text { ristic, compaction }\end{array}$ & $\begin{array}{l}\text { Void In Mix (VIM), Void In Mineral Agreggate (VMA), and Flow decreases, if the compaction } \\
\text { temperature is higher. AC-Base without the addition of PET plastic has higher density, VFA, } \\
\text { and flow values compared to AC-Base with the addition of PET plastic, whereas for VIM, VMA, } \\
\text { and stability values are lower. }\end{array}$ \\
\hline
\end{tabular}

\begin{abstract}
Abstrak
Pada paper ini dibahas efek variasi suhu pemadatan terhadap karaktersitik Marshall pada Campuran Laston Lapis Pondasi (AC-Base) dengan Penambahan Limbah Plastik, jenis Polyethylene Terephthalate (PET). Metode pencampuran limbah plastik PET digunakan metode basah. Variasi suhu pemadatan antara $100^{\circ} \mathrm{C}-180^{\circ} \mathrm{C}$ dengan kenaikan setiap $10^{\circ} \mathrm{C}$. Penelitian ini mengacu pada spesifikasi umum Kementrian Pekerjaan Umum Bina Marga Revisi III tahun 2010. Hasilnya menunjukkan bahwa nilai kepadatan, VFA (Void Filled with Asphalt), Stabilitas, dan MQ (Marshall Quotient) semakin meningkat seiring dengan peningkatan suhu pemadatan, baik pada AC-Base tanpa dan dengan penambahan plastik PET. Sebaliknya, nilai VIM (Void in Mix), VMA (Void in Mineral Agreggate), dan Flow menurun seiring dengan peningkatan suhu pemadatan. AC-Base tanpa penambahan plastik PET memiliki nilai kepadatan, VFA, dan flow yang lebih tinggi dibanding AC-Base dengan penambahan plastik PET, sedangkan untuk nilai VIM, VMA, dan stabilitas lebih rendah.
\end{abstract}

Kata kunci: polyethylene terephthalate, $A C$ base, karakteristik marshall, suhu pemadatan

\section{Pendahuluan}

Sampah botol minuman plastik dengan jenis Polyethylene Terephthalate (PET) yang paling dominan digunakan masyarakat, karena bahan plastik ini memiliki tingkat kejernihan yang tinggi, kaku, memiliki sifat mampu menyimpan gas dan aroma yang lebih lama. Plastik ini hanya bisa satu kali digunakan yang ditandai dengan segitiga berangka satu, sehingga mengakibatkan pembuangannya semakin tidak terkontrol[1].

Pemerintah melalui Kementrian Pekerjaan Umum dan Perumahan Rakyat (PUPR) terus melaksanakan pembangunan proyek infrastruktur jalan. Untuk itu, diperlukan inovasi untuk mencari metode pembangunan alternatif yang dapat meningkatkan efektivitas penggunaan biaya yang ada[1]. Penelitian-penelitian terdahulu menjelaskan bahwa penambahan limbah plastik PET dapat meningkatkan mutu pada campuran aspal beton dan mengurangi biaya konstruksi [2].

Proses pembuatan campuran yang homogen antara aspal, plastik, dan agregat membutuhkan suhu tinggi. Kenyataannya, aspal beton sulit menjaga suhunya dari AMP (Asphalt Mixing Plant) menuju lokasi proyek[2]. Dengan demikian, perlu adanya penelitian lanjutan untuk mengetahui suhu pemadatan minimum dan optimum pada Campuran Laston Lapis Pondasi (AC-Base) agar memenuhi spesifikasi yang ada[3].

Adapun beberapa batasan dalam penelitian ini yaitu proporsi campuran menggunakan proporsi penelitian Derina Septia Pertiwi, 2018[4], perkerasan aspal beton lapis pondasi (AC-Base), aspal penetrasi 60/70, plastik Polyethylene Terephthalate (PET), metode pencampuran metode basah, 
dan variasi suhu pemadatan $100^{\circ} \mathrm{C}, 110^{\circ} \mathrm{C}, 120^{\circ} \mathrm{C}, 130^{\circ} \mathrm{C}$, $140^{\circ} \mathrm{C}, 150^{\circ} \mathrm{C}, 160^{\circ} \mathrm{C}, 170^{\circ} \mathrm{C}$, dan $180^{\circ} \mathrm{C}$.

\section{Metode}

Secara garis besar, tahapan dalam penelitian ini dibagi menjadi pembuatan benda uji AC-Base tanpa penambahan plastik, pembuatan benda uji AC-Base dengan penambahan plastik, analisa, pembahasan, dan penarikan kesimpulan.

Tahapan pembuatan benda uji yaitu menimbang dan memanaskan agregat sesuai proporsi, menimbang dan memanaskan aspal, mencampurkan agregat dan aspal, mengaduk campuran AC-Base hingga homogen, memadatkan menggunakan mesin automatic compactor dengan 75 tumbukan pada kedua sisi permukaan benda uji, melakukan pengujian Marshall.

Perbedaan tahapan benda uji AC-Base tanpa dan dengan penambahan plastik PET terdapat pada saat sebelum proses pencampuran agregat dan aspal. Plastik PET ditambahkan pada aspal yang dipanaskan hingga suhu $180^{\circ} \mathrm{C}$ sehingga disebut metode basah. Plastik PET dan aspal diaduk hingga homogen kemudian dicampur dengan agregat.

Tahapan analisa dan pembahasan pada penelitian ini meliputi uji karakteristik marshall yaitu nilai kepadatan, VIM, VMA, VFA, Stabilitas, Flow, dan Marshall Quotient. Jika tahapan analisa dan pembahasan telah selesai maka dapat dilakukan penarikan kesimpulan.

\section{Hasil dan Pembahasan}

Efek variasi suhu pemadatan Campuran Laston Lapis Pondasi (AC-Base) dengan penambahan limbah plastik PET dapat dilihat pada perubahan karakteristik Marshall. Karakteristik Marshall Properties pada penelitian ini dapat dilihat dari: nilai kepadatan, VIM (Void in Mix), VMA (Void in Mineral Aggregate), VFA (Void Filled Asphalt), Flow, Stabilitas, and MQ.

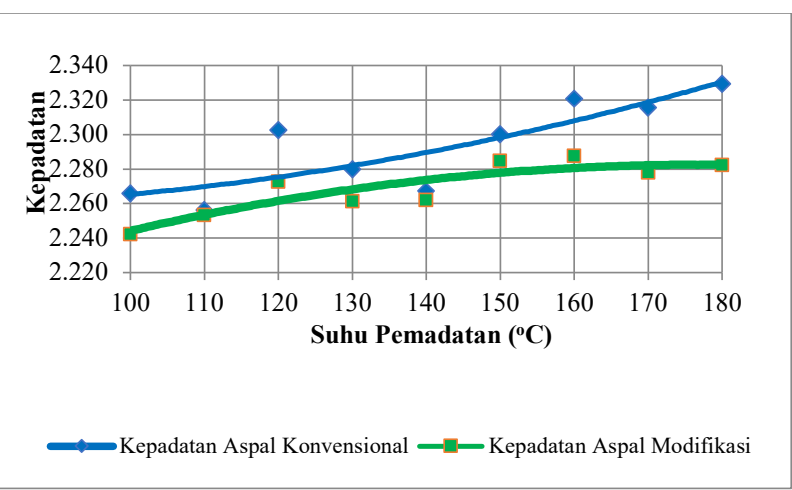

Gambar 1. Grafik Hubungan Suhu Pemadatan dan Kepadatan
Gambar 1 memperlihatkan hubungan suhu pemadatan AC-Base konvensional dan modifikasi terhadap kepadatan cenderung naik seiring meningkatnya suhu pemadatan. Pada suhu pemadatan tinggi AC-Base mengalami pemadatan optimal sehingga meningkatnya nilai kepadatan. Pada suhu rendah, AC-Base memiliki banyak rongga yang tidak dapat terisi aspal maupun agregat akibat tidak mengalami pemadatan yang optimal sehingga kurang padat[4].

Nilai kepadatan AC-Base modifikasi lebih rendah daripada AC-Base konvensional. Hal ini dikarenakan plastik ikut terselimuti aspal dan mengurangi kadar aspal yang seharusnya mengisi rongga pada AC-Base. Semakin sedikit rongga yang terisi oleh aspal maka kadar pori dalam campuran semakin tinggi. Akibatnya campuran AC-Base dengan plastik menjadi kurang padat daripada yang tanpa plastik[2].

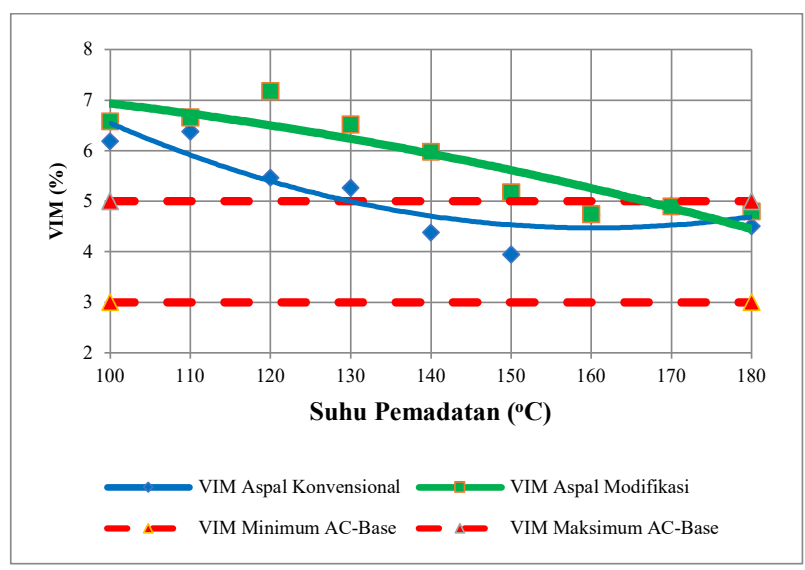

Gambar 2. Grafik Hubungan Suhu Pemadatan dan VIM

Gambar 2 menunjukkan nilai VIM campuran AC-Base pada pengujian AC-Base konvensional dan modifikasi cenderung menurun seiring meningkatnya suhu pemadatan. Spesifikasi umum Bina Marga 2010 nilai VIM untuk $A C$ Base memiliki syarat minimum $3 \%$ dan maksimum $5 \%$, sehingga pada AC-Base konvensional hanya pada suhu pemadatan $140^{\circ} \mathrm{C}$ hingga $180^{\circ} \mathrm{C}$ yang memenuhi, sedangkan pada AC-Base konvensional hanya pada suhu pemadatan $160^{\circ} \mathrm{C}$ hingga $180^{\circ} \mathrm{C}$ yang memenuhi. Hal ini dikarenakan pada suhu pemadatan rendah aspal sulit menyelimuti agregat sehingga aspal dan agregat tidak dapat tercampur secara homogen[3],[6].

Nilai VIM AC-Base modifikasi lebih tinggi daripada ACBase konvensional disebabkan plastik yang ditambahkan menghalangi kadar aspal yang seharusnya mengisi rongga dalam campuran. Semakin banyak rongga yang tidak terisi oleh aspal mengakibatkan pori-pori dalam campuran semakin banyak, sehingga campuran AC-Base modifikasi tidak kedap air dan udara yang dapat terjadi proses oksidasi yang menjadikan AC-Base menjadi crack[2]. 


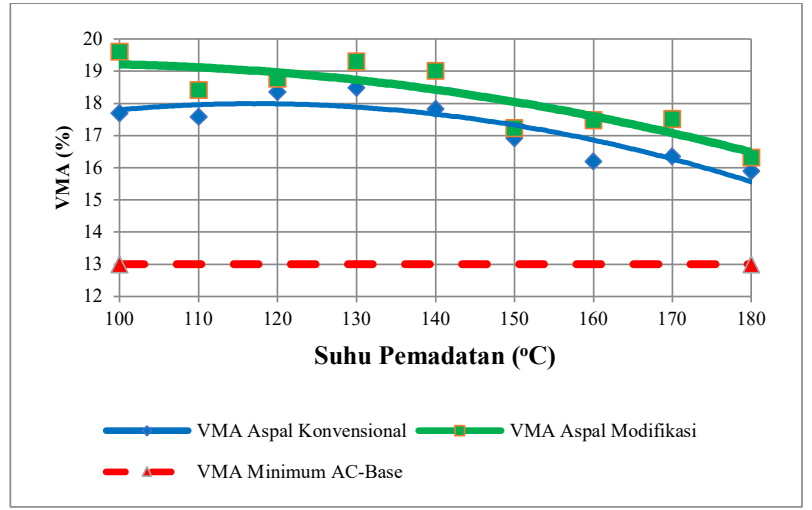

Gambar 3. Grafik Hubungan Suhu Pemadatan dan VMA

Gambar 3 menunjukkan hubungan suhu pemadatan terhadap VMA pada pengujian AC-Base konvensional dan modifikasi menghasilkan data seiring dengan peningkatan suhu pemadatan maka nilai VMA cenderung menurun. Semua nilai VMA pengujian variasi suhu pemadatan memenuhi spesifikasi umum Bina Marga 2010 yaitu minimum $13 \%$ untuk $A C$-Base. Nilai VMA yang rendah pada suhu pemadatan tinggi dikarenakan AC-Base mengalami pemadatan yang optimal sehingga aspal dan plastik dapat mengisi rongga. Rongga yang sedikit mengakibatkan butiran antar agregat menjadi lekat dan tidak mudah lepas[3],[6].

Nilai VMA AC-Base modifikasi lebih rendah daripada AC-Base konvensional. Hal ini dikarenakan plastik yang ditambahkan menghalangi kadar aspal yang seharusnya mengisi rongga dalam campuran. Semakin banyak rongga yang tidak terisi oleh aspal mengakibatkan pori-pori dalam campuran semakin banyak, Rongga yang banyak mengakibatkan butiran antar agregat menjadi tidak lekat dan mudah lepas[7].

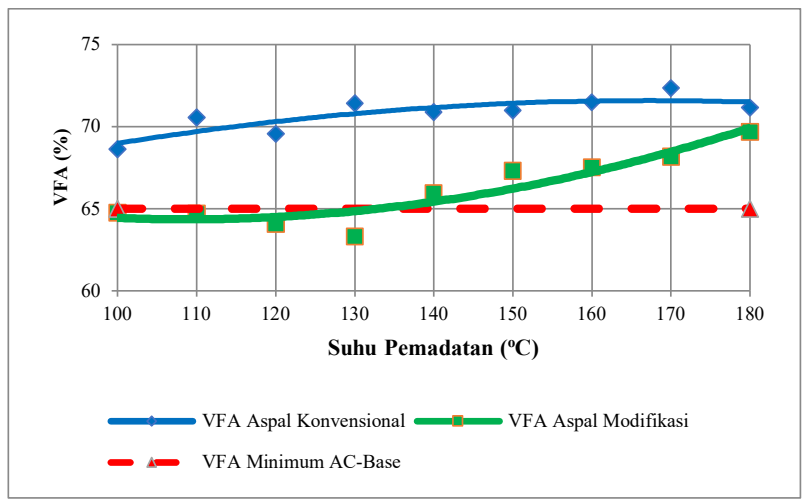

Gambar 4. Grafik Hubungan Suhu Pemadatan dan VFA

Pada Gambar 4 tampak hubungan suhu pemadatan terhadap VFA pada pengujian AC-Base konvensional dan modifikasi menunjukkan data seiring dengan peningkatan suhu pemadatan maka nilai VFA cenderung meningkat. Spesifikasi umum Bina Marga 2010 nilai VFA untuk $A C$ Base memiliki syarat minimum $65 \%$, sehingga semua suhu pemadatan pada AC-Base konvensional yang memenuhi, sedangkan pada AC-Base konvensional hanya pada suhu pemadatan $140^{\circ} \mathrm{C}$ hingga $180^{\circ} \mathrm{C}$ yang memenuhi. Nilai VFA rendah dikarenakan pada suhu pemadatan yang rendah $\mathrm{AC}$ Base memiliki pori-pori dalam jumlah yang banyak atau biasa disebut porus yang menyebabkan kemampuan menyerap air dan oksigennya terlalu tinggi dan terjadi oksidasi[3],[6].

Nilai VFA AC-Base modifikasi lebih rendah daripada AC-Base konvensional. Hal ini disebabkan plastik yang ditambahkan menghalangi kadar aspal yang seharusnya mengisi rongga dalam campuran. Semakin banyak rongga yang tidak terisi oleh aspal mengakibatkan pori-pori dalam campuran semakin banyak yang mengakibatkan AC-Base menjadi porus[2].

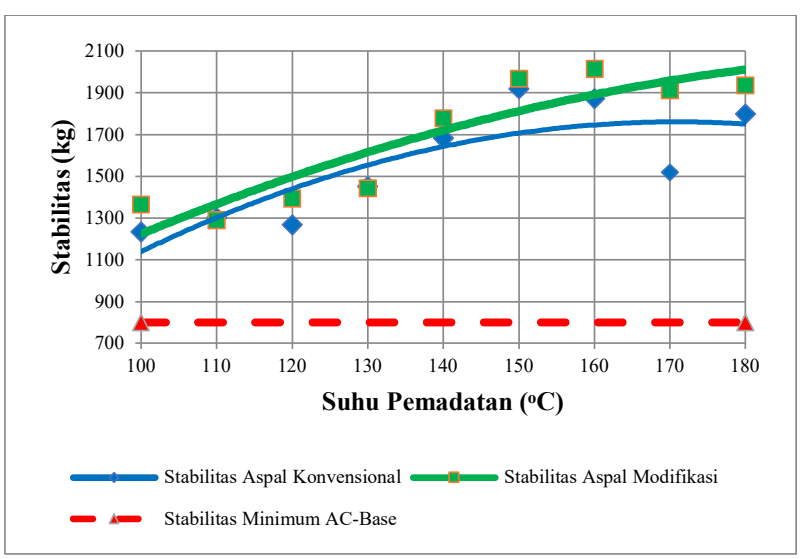

Gambar 5. Grafik Hubungan Suhu Pemadatan dan Stabilitas

Gambar 5 memperlihatkan hubungan suhu pemadatan terhadap nilai stabilitas AC-Base konvensional dan modifikasi cenderung mengalami peningkatan seiring dengan peningkatan suhu pemadatan. Suhu pemadatan tinggi mengakibatkan AC-Base mengalami pemadatan optimal sehingga antar partikel dapat mengunci satu dengan yang lain untuk meningkatkan daya ikat[6].

Nilai stabilitas AC-Base modifikasi lebih tinggi daripada AC-Base konvensional dikarenakan plastik yang ditambahkan berbentuk serat bersudut dan agregat yang terselimuti aspal saling mengunci dengan baik. Posisi agregat tidak mudah bergeser dari tempatnya ketika diberi beban, sehingga stabilitasnya [2]. 


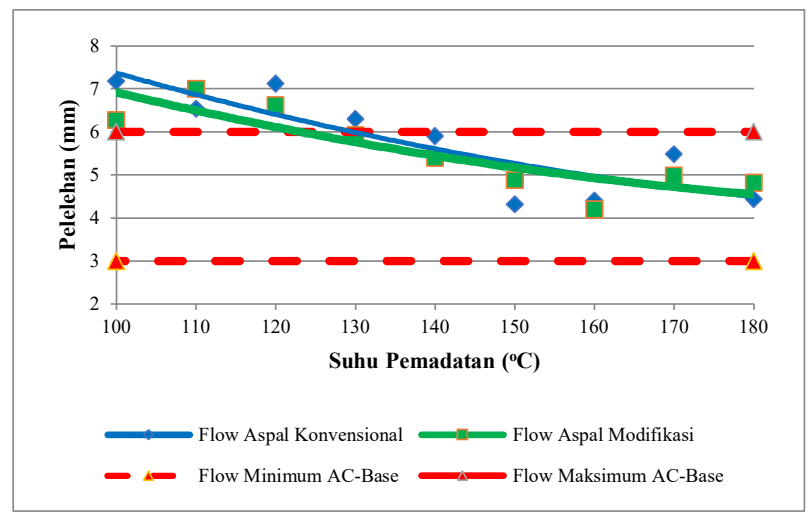

Gambar 6. Grafik Hubungan Suhu Pemadatan dan Flow

Gambar 6 menunjukkan hubungan suhu pemadatan terhadap flow pada pengujian AC-Base konvensional dan modifikasi menunjukkan data seiring dengan peningkatan suhu pemadatan maka nilai flow cenderung menurun. Spesifikasi umum Bina Marga 2010 untuk AC-Base mensyaratkan nilai flow antara $3 \mathrm{~mm}-6 \mathrm{~mm}$, sehingga pada AC-Base konvensional hanya pada suhu pemadatan $140^{\circ} \mathrm{C}$ hingga $180^{\circ} \mathrm{C}$ yang memenuhi, sedangkan pada AC-Base modifikasi hanya pada suhu pemadatan $130^{\circ} \mathrm{C}$ hingga $180^{\circ} \mathrm{C}$ yang memenuhi. Flow yang terlalu tinggi maupun terlalu rendah tidak baik untuk AC-Base. Nilai flow yang terlalu tinggi mengindikasikan campuran yang bersifat plastis dan lebih mampu mengikuti deformasi akibat beban, sedangkan flow yang terlalu rendah mengisyaratkan campuran tersebut memiliki rongga tidak terisi aspal yang lebih tinggi dari kondisi normal atau kandungan aspal yang terlalu rendah sehingga berpotensi retak dini dan durabilitas rendah[3],[6].

Nilai Flow AC-Base konvensional lebih tinggi daripada AC-Base modifikasi. Hal ini disebabkan karena kadar aspal pada AC-Base konvensional lebih banyak dibanding ACBase modifikasi. Kadar aspal yang lebih banyak mengakibatkan AC-Base menjadi lunak dan meningkatkan nilai pelelehan[2].

Gambar 7 menunjukkan hubungan suhu pemadatan ACBase konvensional dan modifikasi terhadap nilai marshall quotient cenderung meningkat seiring meningkatnya suhu pemadatan. Nilai marshall quotient pada spesifikasi umum Bina Marga 2010 minimal $250 \mathrm{~kg} / \mathrm{mm}$ untuk AC-Base, sehingga pada AC-Base konvensional hanya pada suhu pemadatan $140^{\circ} \mathrm{C}$ hingga $180^{\circ} \mathrm{C}$ yang memenuhi, sedangkan pada $\mathrm{AC}$-Base modifikasi hanya pada suhu pemadatan $130^{\circ} \mathrm{C}$ hingga $180^{\circ} \mathrm{C}$ yang memenuhi. Nilai MQ meningkat pada suhu tinggi dikarenakan stabilitas naik pada suhu tersebut menyebabkan AC-Base semakin kaku sedangkan untuk nilai flow yang dihasilkan rendah. Nilai MQ AC-Base modifikasi lebih tinggi daripada AC-Base konvensional[2],[3],[7].

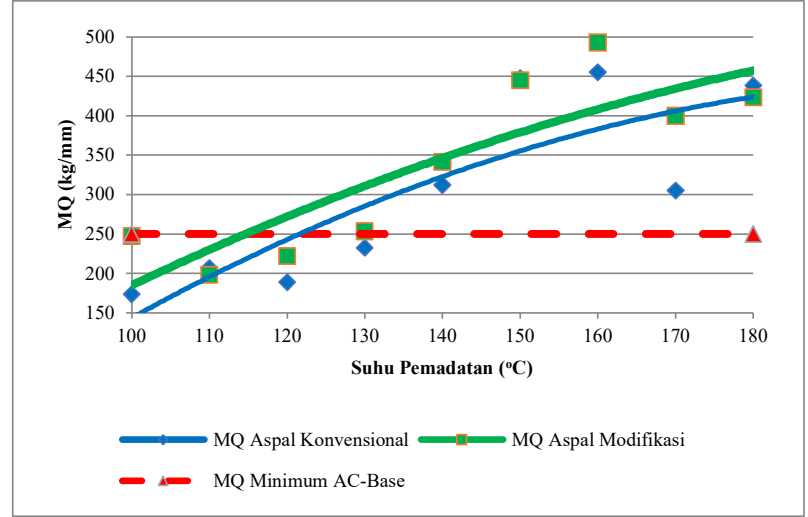

Gambar 7. Grafik Hubungan Suhu Pemadatan dan Marshall Quotient

\section{Simpulan}

Dari penelitian ini dapat diambil beberapa kesimpulan sebagai berikut:

1. Hasil uji karakterstik marshall pada AC-Base konvensional dan modifikasi menunjukkan bahwa nilai kepadatan, VFA, stabilitas, dan MQ meningkat seiring dengan peningkatan suhu pemadatan, sedangkan nilai VIM, VMA, dan Flow menurun.

2. Hasil uji karakteristik marshall diketahui bahwa ACBase konvensional memiliki nilai kepadatan, VFA, dan flow yang lebih tinggi dibanding AC-Base modifikasi, sedangkan untuk nilai VIM, VMA, dan stabilitas lebih rendah.

3. Pada AC-Base konvensional diperoleh suhu minimum sebesar $140{ }^{\circ} \mathrm{C}$ dan suhu optimum sebesar $150^{\circ} \mathrm{C}$, sedangkan pada AC-Base modifikasi diperoleh suhu minimum dan optimum sebesar $160^{\circ} \mathrm{C}$.

\section{Daftar Pustaka}

[1] I. Susanto and N. Suaryana, "Evaluasi Kinerja Campuran Beraspal Lapis Aus ( AC-WC ) dengan Bahan Tambah Limbah Plastik Kresek," J. Apl. Tek. Sipil, vol. 17, no. 2, pp. 27-36, 2019.

[2] P. E. Purnamasari and F. Suryaman, "Pengaruh Penggunaan Limbah Botol Plastik Sebagai Bahan Tambah Terhadap Karakteristik Lapis Aspal Beton ( Laston )," Konf. Nas. Tek. Sipil 4 (KoNTekS 4), vol. 4, no. KoNTekS 4, pp. 2-3, 2010.

[3] Dirjen Bina Marga, "Spesifikasi Umum Bidang Jalan dan Jembatan Revisi 3," Kementrian Pekerjaan Umum, Indonesia, 2010.

[4] Pratiwi, D. S. (2018). Pengaruh Suhu Pemadatan Terhadap Karakteristik Hasil Uji Marshall Untuk Campuran Laston Lapis Pondasi (AC-BASE) Dengan Penambahan Plastik Tipe Polyethylene Terephthalate 
(PET). Undergraduate thesis, Institut Teknologi Sepuluh Nopember.

[5] I. Aschuri and R. P. Rizal, "Kajian Suhu Optimum pada Proses Pemadatan Menggunakan Modifikasi Bitumen Limbah,” J. Tek. Sipil, 2011.

[6] B. Raharjo, P. Pratomo, and H. Ali, "Pengaruh Suhu Pemadatan Campuran Untuk Perkerasan Lapis Antara ( AC-BC ) Campuran aspal panas merupakan salah satu jenis dari lapis perkerasan konstruksi," JSRDD, vol. 4, no. 1, pp. 43-50, 2016.

[7] L. Widojoko and P. E. Purnamasari, "Study the Use of Cement and Plastic bottle Waste as Ingredient Added to the Asphaltic Concrete Wearing Course," Procedia - Soc. Behav. Sci., vol. 43, pp. 832-841, 2012. 
